DOI: $10.31471 / 2311-1399-2019-1(11)-1-6$

\title{
Intensification of gas production from fields with unstable reservoirs
}

\author{
R.M. Kondrat, O.R. Kondrat, N.S. Dremlyukh*, A.V. Ugrynovsky \\ Ivano-Frankivsk National Technical University of Oil and Gas; \\ 15, Karpatska Str., Ivano-Frankivsk, 76019, Ukraine
}

Received: 12.06.2019 Accepted: 14.06.2019

\begin{abstract}
The negative consequences of sand removal from the reservoir and methods of preventing the formation of sand plugs at the bottom of wells are indicated. According to the results of research on the well model, the minimum required gas velocities have been experimentally determined for the removal of sand particles of three different fractions. The optimal concentrations of foaming surface active substances (surfactants) and stabilizers in aqueous solutions have been chosen in order to obtain stable foam for sand plugs flushing on the wells. There has been experimentally set the velocity of the foam with the addition and without the addition of a foam stabilizer for the transfer of solid particles from the well. Two compositions of foaming surfactants and stabilizers have been developed, one of which is proposed for sand plugs flushing at the bottom of the well, and the other for dosed injection into the annulus of the well to prevent accumulation of the solid phase at the bottom.

Theoretical studies have substantiated the choice of the well bore diameter in the gas-bearing formation zone depending on the well productivity and determined the optimal values of the thickness and permeability of the gravel pack in the bottom hole zone of the well with unstable reservoirs, which prevent sand from passing the formation to the well. Theoretical studies have substantiated a rational correlation of diameters of tubing, columns of flexible pipes and the flow rate of the flushing agent for washing the sand plug in the wells with various flushing agents. The composition of the slurry solution has been chosen to create a cement stone with high values of strength and permeability in the bottomhole formation zone. To increase the efficiency and reduce the time and costs there has been proposed a device for the destruction of sand plugs, which consists of a housing with a check valve. A patent-protected design of the device for repairing the lower part of the production casing, damaged as a result of erosion destruction by particles of formation sand, has been proposed. An improved technology for improving the productivity of gas wells with unstable reservoirs has been offered.
\end{abstract}

Keywords: cement slurry, cement stone, foam, gas, lift pipes, sand plug.

One of the main problems in maintaining the productivity of wells during operation of wells with unstable reservoirs is to prevent the destruction of the bottom-hole zone of the formation and the elimination of sand plugs at the bottom of the well.

The process of destruction of the bottom-hole formation zone is complex and depends on many factors. In addition to geological conditions, complications are associated with sand breakdowns, largely due to the technology of primary and secondary opening of productive deposits, methods of well development and the nature of their operation.

The presence of sand plugs leads to a decrease in well flow rates and can cause the accumulation of tubing during operation. In the presence of particles of a solid phase in the gas produced, the downhole and ground equipment is subjected to erosive wear, which is another reason for the withdrawal of production wells from the existing fund [1].

A number of studies have been devoted to preventing sand entering the well and eliminating sand

* Corresponding author:

Nataliadremluh@ukr.net

(C) 2019, Ivano-Frankivsk National Technical

University of Oil and Gas.

All rights reserved. plugs at the bottom of the well. Methods for preventing the destruction of the bottom-hole formation zone include fixing rocks in the bottom-hole zone with cement-sand mixtures, cement mortar, resins, etc., however, most of the proposed compositions for bonding unstable rocks do not provide a sufficiently high efficiency of rock strengthening while preserving the filtration characteristics of the formation. Therefore, of particular interest is the use of cement compositions to create a cement stone with the required strength and permeability values in the bottomhole formation zone.

Sand plugs at the bottom of the well are most often eliminated by washing with various flushing agents. The use of water or an aqueous solution of various chemicals as a flushing agent is ineffective in depleted fields with abnormally low reservoir pressures due to intensive absorption of flushing fluid by the reservoir, which is then difficult to remove from the reservoir. Part of the sand from the sand plug, along with water, penetrates the reservoir and plugs it. This increases the duration of the well development process and reduces the current gas flow rate. So, it is urgent to develop a composition of a washing agent with a low density (in particular, foam of high multiplicity and significant stability) for washing sand plugs at the bottom of a well in depleted fields.

In the case of sand inflow from the formation into the well, it is necessary to prevent its accumulation in 
the bottom by continuous removal to the surface. An effective method of removing solid phase particles from the well is the use of foam systems, the justification of the composition of which requires additional research.

One of the urgent problems of natural gas production during destruction of the bottom-hole zone of the formation and intensive removal of the solid phase is to increase the efficiency of the operation of underground and ground equipment in wells under conditions of erosion wear. In this regard, there is a need to develop a device for the repair of production casing damaged as a result of erosion destruction by particles of the solid phase, which are carried out from unstable reservoir rocks.

To prevent the entry of sand from the formation into the well, the composition of the slurry solution was chosen to create a cement stone in the bottom-hole zone of the formation with the corresponding strength and permeability values [2]. TC-100 cement slurry, expanded perlite fraction $0.16-1.25 \mathrm{~mm}$, nonionic surfactants, plasticizer and water were used as starting materials for the creation of the slurry solution.

To choose the optimal composition of the cement slurry, laboratory studies were conducted to determine the spreadability and density of the cement slurry, compressive strength, and gas permeability of the cement stone.

To determine the content of expanded perlite in the composition, which will provide the necessary strength of the stone while maintaining the permeability of the rock, a graphical dependence is constructed, which is shown in Figure 1. According to the results of experimental studies, the optimal content of expanded perlite is $3.0-3.5 \%$ by mass. At these concentrations, we obtain the necessary compressive strength of the stone while preserving the filtration properties of the collector.

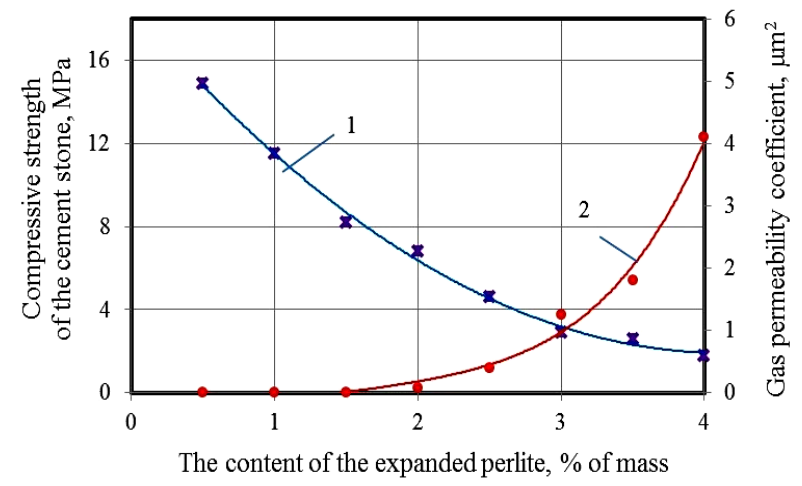

Figure 1 - Dependences of the strength of cement stone on compression (1) and the coefficient of permeability of stone (2) on the content of expanded perlite

The spreadability of the cement slurry with the content of expanded perlite $3.0-3.5 \%$ of the mass is 190 and $185 \mathrm{~mm}$, respectively, which is technologically convenient for preparing and storing the solution in the well.

According to the results of experimental studies, the mass concentration of the individual components in the cement slurry is as follows: cement slurry $62.85-$
$63.5 \%$, expanded perlite $3.0-3.5 \%$, nonionic surfactant $0.3-0.35 \%$, plasticizer $0.1 \%$, water is the rest. The formed cement stone is characterized by high values of mechanical compressive strength (up to $4 \mathrm{MPa}$ ) and gas permeability (up to $3.47 \mu \mathrm{m}^{2}$ ).

One of the ways to increase the productivity of wells with unstable reservoirs is to expand the borehole diameter in the interval of the reservoir.

The effect of the wellbore diameter in the interval of the reservoir on the gas flow, the depression on the reservoir and the pressure gradient on the well wall were investigated (Table 1).

According to the calculation results for each of the studied initial values of gas production and depression per formation, it follows that with increasing radius of the wellbore in the interval of the productive formation, there decrease depression in the formation, pressure gradient on the bottom wall of the well, and gas production increases.

With the same multiplicity of increasing the radius of the wellbore, the degree of decrease in pressure depression on the formation is the greater, the higher the initial gas production (the highest for a high-production well with a gas production of 500 thousand $\mathrm{m}^{3} / \mathrm{d}$ and the lowest for a low-production well with a gas production of 25 thousand $\mathrm{m}^{3} / \mathrm{d}$ ).

Using the Golden Section Method, the optimal value of the multiplicity of increasing the diameter of the wellbore was determined, above which the gas production rate does not change much: for lowproduction wells - from 13.92 times to 5.2 times; for medium production wells - 2.1 times; for high-yield wells -1.04 times. The multiplicity of increasing the diameter of the wellbore by 13.92 times for low production wells is economically impractical and technically impossible. Therefore, it is necessary to limit oneself to a less economically feasible and technically perfect degree of increasing the diameter of the wellbore. When the borehole is expanded by a certain amount, the destruction of the bottomhole formation zone is prevented.

To combat the removal of sand from the formation into the well, there are used gravel and alluvial filters in industrial practice. In order to choose the optimal gravel filter design, there have been performed theoretical studies of the influence of the thickness and permeability of the artificially created gravel pack in the bottomhole formation zone on the productive characteristics of the well, the results of which are shown in Figure 2.

According to the results of theoretical studies, the flow rate of a gas well with gravel packing (gravel filter) increases with increasing thickness and permeability of gravel packing [4]. The gas production rate increases most significantly with an increase in the permeability ratio of gravel pack and productive formation $k_{2} / k_{1}$ up to 3 times.

Based on the results of statistical processing of the calculated data by the least squares method, there was established the ratio of the permeability of the gravel pack and the reservoir (2.4), and the thickness of the gravel pack $(0.4 \mathrm{~m})$, above which the gas flow rate does 
Table 1 - The magnitude of the change in the flow rate of the well $\delta_{q}$, depression on the reservoir $\delta_{\Delta p}$ and the pressure gradient $\delta_{\text {grad } P}$ from the ratio of the increase in the radius of the wellbore in the interval of the reservoir

\begin{tabular}{|c|c|c|c|c|c|c|c|c|c|c|c|c|}
\hline \multirow{2}{*}{$n$ times } & \multicolumn{3}{|c|}{$q=25 \cdot 10^{3}, \mathrm{~m}^{3} / \mathrm{day}$} & \multicolumn{3}{c|}{$q=90 \cdot 10^{3}, \mathrm{~m}^{3} / \mathrm{day}$} & \multicolumn{3}{c|}{$q=250 \cdot 10^{3}, \mathrm{~m}^{3} / \mathrm{day}$} & \multicolumn{3}{|c|}{$q=500 \cdot 10^{3}, \mathrm{~m}^{3} / \mathrm{day}$} \\
\cline { 2 - 14 } & $\delta_{\Delta p}$ & $\delta_{q}$ & $\delta_{\text {grad } P}$ & $\delta_{\Delta p}$ & $\delta_{q}$ & $\delta_{\text {grad } P}$ & $\delta_{\Delta p}$ & $\delta_{q}$ & $\delta_{\text {grad } P}$ & $\delta_{\Delta p}$ & $\delta_{q}$ & $\delta_{\text {grad } P}$ \\
\hline 1.0 & 1 & 1 & 1 & 1 & 1 & 1 & 1 & 1 & 1 & 1 & 1 & 1 \\
\hline 1.5 & 0.953 & 1.050 & 0.655 & 0.948 & 1.053 & 0.631 & 0.932 & 1.064 & 0.584 & 0.906 & 1.076 & 0.550 \\
\hline 2.0 & 0.920 & 1.086 & 0.487 & 0.912 & 1.093 & 0.46 & 0.889 & 1.111 & 0.407 & 0.851 & 1.131 & 0.369 \\
\hline 2.5 & 0.894 & 1.117 & 0.388 & 0.885 & 1.125 & 0.362 & 0.858 & 1.148 & 0.311 & 0.813 & 1.175 & 0.274 \\
\hline 3.0 & 0.874 & 1.143 & 0.322 & 0.864 & 1.153 & 0.298 & 0.833 & 1.179 & 0.251 & 0.784 & 1.211 & 0.217 \\
\hline 3.5 & 0.856 & 1.166 & 0.275 & 0.846 & 1.177 & 0.253 & 0.813 & 1.206 & 0.210 & 0.761 & 1.242 & 0.179 \\
\hline 4.0 & 0.841 & 1.187 & 0.240 & 0.830 & 1.198 & 0.220 & 0.796 & 1.230 & 0.181 & 0.742 & 1.269 & 0.152 \\
\hline 4.5 & 0.828 & 1.206 & 0.213 & 0.816 & 1.218 & 0.195 & 0.782 & 1.252 & 0.158 & 0.726 & 1.294 & 0.132 \\
\hline 5.0 & 0.816 & 1.223 & 0.192 & 0.804 & 1.236 & 0.175 & 0.769 & 1.272 & 0.141 & 0.712 & 1.316 & 0.116 \\
\hline 5.5 & 0.805 & 1.240 & 0.174 & 0.793 & 1.253 & 0.158 & 0.757 & 1.290 & 0.127 & 0.699 & 1.336 & 0.104 \\
\hline 6.0 & 0.796 & 1.255 & 0.159 & 0.783 & 1.268 & 0.145 & 0.747 & 1.307 & 0.115 & 0.688 & 1.355 & 0.094 \\
\hline 7.0 & 0.778 & 1.820 & 0.136 & 0.766 & 1.297 & 0.123 & 0.729 & 1.339 & 0.098 & 0.669 & 1.390 & 0.079 \\
\hline 8.0 & 0.763 & 1.307 & 0.119 & 0.751 & 1.322 & 0.108 & 0.713 & 1.366 & 0.084 & 0.652 & 1.420 & 0.068 \\
\hline 9.0 & 0.750 & 1.330 & 0.106 & 0.737 & 1.346 & 0.095 & 0.699 & 1.392 & 0.075 & 0.638 & 1.448 & 0.059 \\
\hline 10.0 & 0.739 & 1.351 & 0.095 & 0.726 & 1.368 & 0.086 & 0.687 & 1.415 & 0.067 & 0.626 & 1.474 & 0.053 \\
\hline 11.0 & 0.728 & 1.371 & 0.087 & 0.715 & 1.388 & 0.078 & 0.677 & 1.436 & 0.060 & 0.615 & 1.497 & 0.048 \\
\hline 12.0 & 0.718 & 1.389 & 0.079 & 0.705 & 1.407 & 0.071 & 0.667 & 1.457 & 0.055 & 0.605 & 1.519 & 0.043 \\
\hline 13.0 & 0.709 & 1.407 & 0.073 & 0.696 & 1.424 & 0.066 & 0.658 & 1.476 & 0.051 & 0.596 & 1.540 & 0.040 \\
\hline 14.0 & 0.701 & 1.423 & 0.068 & 0.688 & 1.441 & 0.061 & 0.649 & 1.494 & 0.047 & 0.588 & 1.559 & 0.037 \\
\hline
\end{tabular}

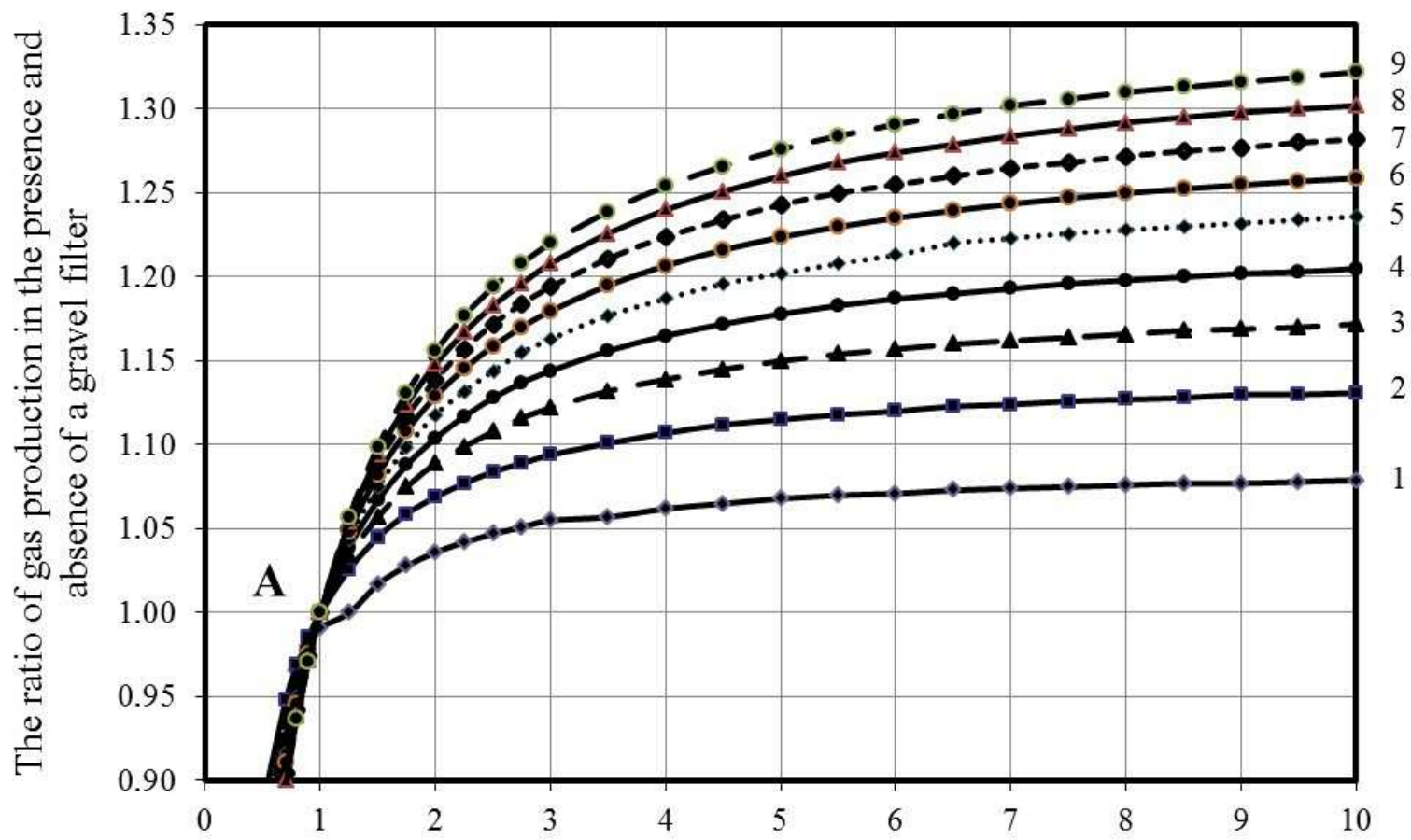

The ratio of the permeability of gravel packing to the reservoir

Radius of the gravel packing, m: $1-0.2 ; 2-0.3 ; 3-0.4 ; 4-0.5 ; 5-0.6 ; 6-0.7 ; 7-0.8 ; 8-0.9 ; 9-1$

Figure 2 - Dependence of the ratio of gas production levels in the presence and absence of gravel packing upon the ratio of permeability of gravel packing and a reservoir for different values of the radius of the gravel packing zone (the radius of the wellbore with a bit of $0.1 \mathrm{~m}$ )

not change. This ratio is recommended to be guided when choosing the diameter of gravel grains to create a gravel filter.
It is not always possible to achieve effective prevention of the formation of sand plugs at the bottom and to ensure the normal operation of wells, and 


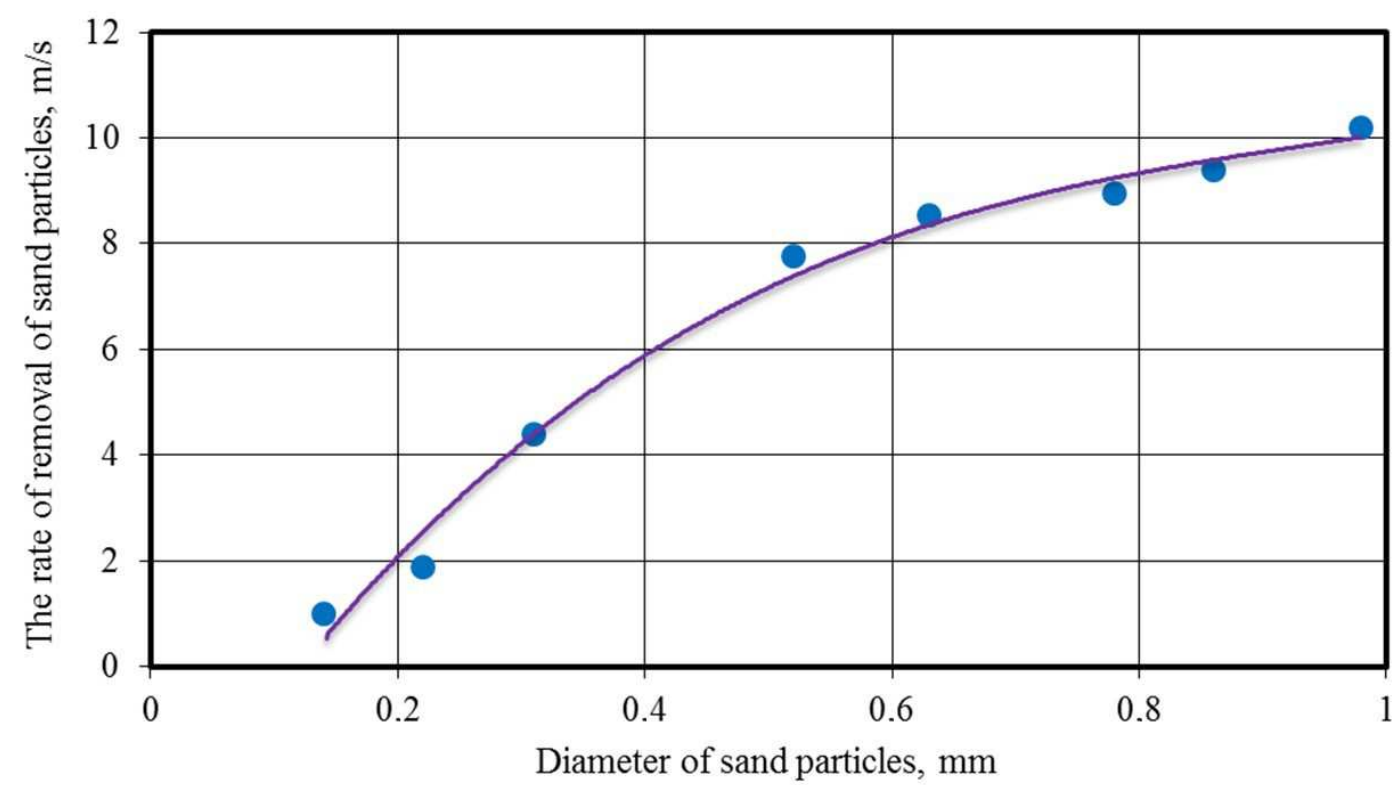

Figure 3 - Graph of the rate of removal of sand particles by gas flow depending on their diameter

therefore sand plugs are periodically formed in the wells, which lead to deterioration of operating conditions. To resume well operation, sand plugs are periodically eliminated.

At present, the elimination of sand plugs in wells is carried out by periodic flushing of wells by the method of fluid circulation, cleaning of hydraulic drills and other devices. The choice of the plug elimination method depends on the degree of plug flowability.

To study the process of removal of solid particles from the bottom of a gas well by a gas stream, there were performed experimental studies on a well model [5]. The experiments were carried out with sand particles of three different fractions $(0.1-0.315$; $0.315-$ $0.63 ; 0.63-1.0 \mathrm{~mm})$. The results of experimental studies are shown in Figure 3.

According to the results of experimental studies on a well model, the minimum necessary velocity for the removal of sand particles with a diameter of 0.1 to $1 \mathrm{~mm}$ from the bottom to the surface by a gas stream varies from 0.985 to $10.2 \mathrm{~m} / \mathrm{s}$. Based on the results of the experimental studies, there is obtained a regression dependence to estimate the necessary gas flow velocity $W(\mathrm{~m} / \mathrm{s})$ for removing sand particles of different diameter $d_{p}(\mathrm{~mm})$ :

$$
W=11.63 d_{p}^{3}-33.68 d_{p}^{2}+36 d_{p}-3.859 .
$$

To remove sand plugs from the bottom of wells in depleted gas fields with low reservoir pressures, it is necessary to use flushing agents with a low density, in particular, foam with high multiplicity and significant stability. To choose compositions of foaming surfactants and foam stabilizers for forming foams with high foaming characteristics, experimental studies were performed with solutions of Savenol SWP, Stinol and Sofir M2 in fresh water with mass concentrations of $0.125 ; 0.25 ; 0.5 ; 1.0 ; 2.0 ; 4.0 \%$ [6]. Carboxymethyl cellulose (CMC) and such natural biopolymers as xanthan and guar gums with mass concentrations of 0.25 and $0.5 \%$ were used as foam stabilizers. The experiments were carried out at temperatures of 20,40, and $60{ }^{\circ} \mathrm{C}$ and atmospheric pressure of $0.1013 \mathrm{MPa}$.

The analysis of the research results shows that when foam stabilizers are added, the multiplicity of the foam decreases, and the stability increases. Solutions of Savenol SWP and Stinol have the highest foam stability in fresh water with xanthan gum. Foam is stable, uniform, gas bubbles are of the same size. Foam stabilizers, xanthan gum and guar gum, which were not previously used in technological processes for eliminating sand plugs in the bottom of the well and removing the liquid with the bottom of the foaming, provide higher foam stability values in comparison with carboxymethyl cellulose, which is used in drilling and well repair.

The results of experimental studies of the removal of solid particles from the model of lift pipes by foam systems are shown in Figure 4.

According to the results of the studies, foams formed from an aqueous solution of stinol with a concentration of $1 \%$ mass in fresh water with the addition of xanthan gum with a concentration of $0.5 \%$ mass have the greatest carrying capacity [7]. The rate of removal of sand particles with a diameter of 0.1 to 1.0 $\mathrm{mm}$ from the well model by the foam flow varies from 0.017 to $0.064 \mathrm{~m} / \mathrm{s}$. According to experimental data, there is proposed a regression dependence of the rate of sand particles removal by the foam $W(\mathrm{~m} / \mathrm{s})$ formed from an aqueous solution of stinol with a concentration of $1 \%$ mass and xanthan gum with a concentration of $0.5 \%$ mass from the particle diameter $d_{p}(\mathrm{~mm})$ :

$$
W=0.023 d_{p}^{2}+0.026 d_{p}+0.014 \text {. }
$$

According to research results there are recommended two compositions of foaming surfactants and foam stabilizers for practical use. The first composition is an aqueous solution of $1.0 \%$ by weight of the foaming surfactant of stinol and $0.5 \%$ by weight of xanthan gum and it is intended for washing sand plugs at the bottom of the well. The second composition 


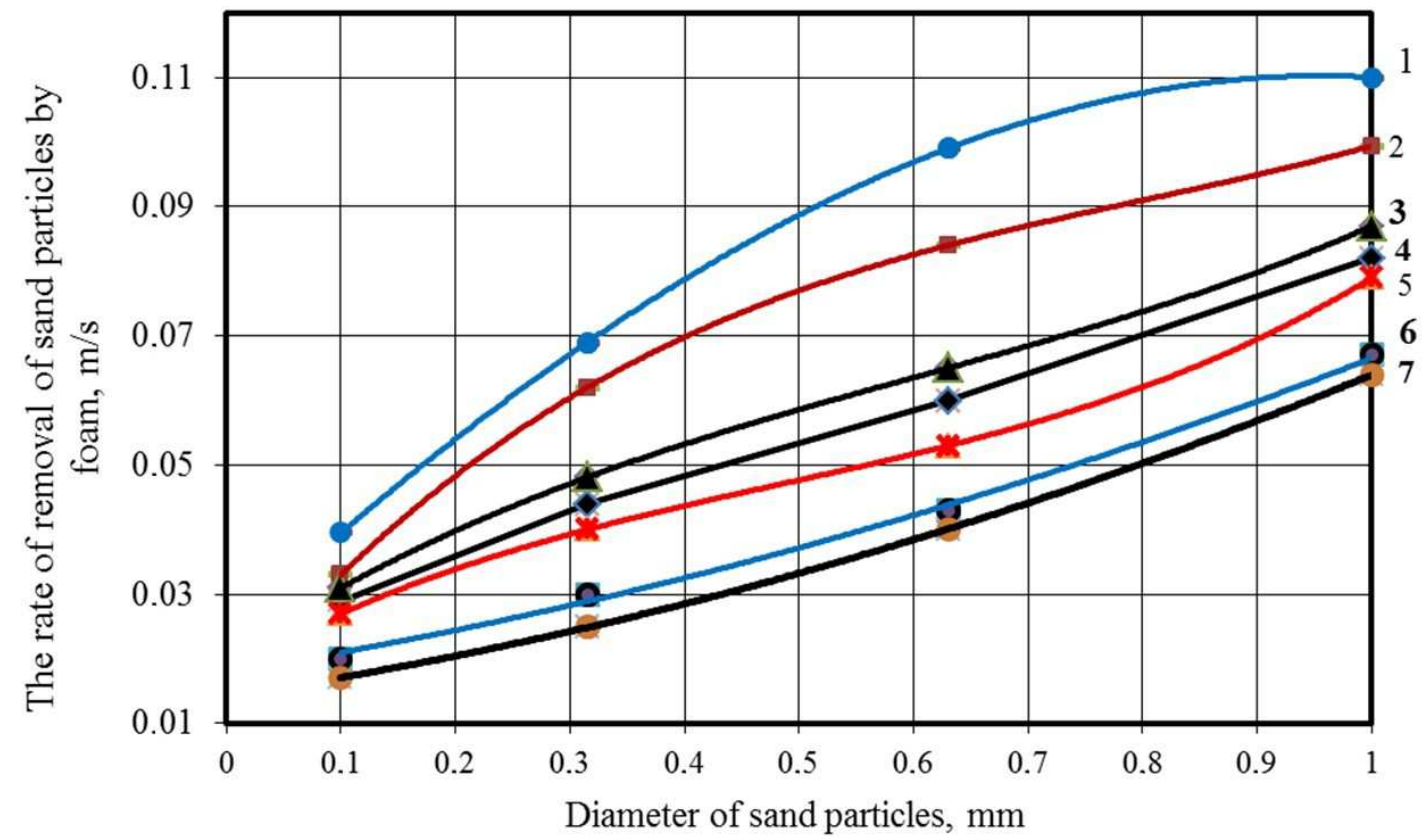

$1-0.5 \%$ of the mass of the savenol SWP; $2-0.5 \%$ of the mass of stinol; $3-1 \%$ of the mass of Savenol SWP; $4-0.5 \%$ of the mass of stinol and $0.5 \%$ of the mass of xanthan gum; $5-1 \%$ of the mass of stinol; $6-1 \%$ of the mass of savenol SWP and $0.5 \%$ of the mass of xanthan gum;

$7-1 \%$ of the mass of stinol and $0.5 \%$ of the mass of xanthan gum

\section{Figure 4 - Graph of the rate of removal of sand particles by foam systems from their diameter at different contents in the working solution of surfactants and foam stabilizers}

is an aqueous solution of $1.0 \%$ of the mass of the foaming surfactant of Stinol or Savenol SWP and $0.5 \%$ of the mass of the stabilizer of the foam of guar gum, is intended for dosed introduction into the annular space of the well in order to prevent accumulation of the bottom solid phase, coming from the formation.

Recently, industrial practice has used the latest coiled tubing technologies with a flexible pipe string to eliminate sand plugs at the bottom of the well.

The main factors that affect the cleaning of the well bottom from sand plugs are the diameters of the production string, tubing and flexible pipe string, through which operations are being carried out, the density of the flushing agent, the size and density of solid particles, the permissible flow rate of the flushing agent, the curvature of the wellbore wells, reservoir pressure and well depth [8].

According to the results of studies of flushing a sand plug at the bottom of the well with different flushing agents (water, hydrophobic-emulsion solution, gaseous agents and foam) using a string of flexible pipes, lowered into the column of tubing, a reasonably rational way to flush sand plugs (direct washing with pumping of the washing agent in the string of flexible pipes), there has been substantiated a rational correlation of a string of flexible pipes and the column of tubing diameters for each washing agent and its flow rate, which ensures a minimum value of downhole pressure and correspondingly decreases the amount of flushing agent absorbed by the reservoir. The lowest bottomhole pressure value was obtained when using foam as a flushing agent, a slightly higher value - when using a gaseous agent (nitrogen).
To loosen the sand cork, various tips are screwed onto the tubing shoe: a short nozzle with a slanted end ("feather") or with a rounded conical end ("pencil") with a hole (diameter $12-37 \mathrm{~mm}$ ), with teeth on the end (milling cutter - mouthpiece) and others [9]. These designs of tips do not provide effective destruction of compressed sand plugs. We have proposed a new design of a device for breaking sand plugs [10]. The device is attached to the bottom of the flushing pipe string. The destruction of the sand plug occurs due to the vibration effect of the device rods under the influence of the pressure of the flushing agent. Pulses of the flushing agent transfer the particles of the solid phase into suspension, which are then easily carried to the surface by the flow of the flushing agent.

In the presence of sand in the reservoir products, a gradual erosion destruction of the lower part of the production string occurs. There has been proposed a patented design of a device for repairing the bottom of a production casing damaged due to erosion by particles of formation sand, which allows repairing several damages along the length of the casing and eliminating irregularities on the surface of the casing.

There has been improved the technology of intensification of wells operation with unstable reservoirs, which includes the expansion in the interval of the reservoir during the construction of the well by a predetermined size of the well and filling the formed hollow space (or the formed caverns during the longterm operation of the wells) with cement slurry, which forms a cement stone of high strength and permeability; flushing the sand plug at the bottom of the well with an aqueous solution of a foaming surfactant and a foam 
stabilizer along a string of flexible pipes, the bottom of which is equipped with a device for breaking the sand plug; dosed introduction of an aqueous solution of a foaming surfactant and a foam stabilizer into the annulus of the well to remove solid particles from the wells and the use of a device to eliminate erosion damages with formation sand at the bottom of the production string.

\section{References}

[1] Kondrat, RM \& Dremlyukh, NS 2018, 'Improving the efficiency of operation of wells with unstable reservoirs in depleted gas fields', Oil and gas industry of Ukraine, no. 6, pp. 18-22. [in Ukrainian]

[2] Pat. no. 113026 Ukraine, IPC E 21 B33/138, 'Composition for mounting unstable collector rocks', R.M. Kondrat, N.S. Dremlyukh, Yu. I. Kovalchuk, no. 201606383, application 13.06.2016, publ. 01/01/2017, bul 1. [in Ukrainian]

[3] Kondrat, RM, Gorbichuk, MI \& Dremlyukh, NS 2017, 'Investigation of the effect of barrel diameter on the productivity of gas wells', Exploration and development of oil and gas fields, no. 3 (64), pp. 92-101. [in Ukrainian]

[4] Kondrat, RM \& Dremlyukh, NS 2016, 'Study on the effect of the size and permeability of the artificially created near-wellbore zone of the formation on the productive characteristics of the well', Scientific Bulletin of IFNTUNG, no. 1 (40), pp. 14-19. [in Ukrainian]
[5] Kondrat, RM, Dremlyukh, NS, Ugrynovsky, AV \& Ksenych, AI 2015, 'Experimental study of the rate of removal of a solid phase by gas flow from the bottom of a well to the surface', Exploration and development of oil and gas fields, no. 3 (56), pp. 106-112. [in Ukrainian]

[6] Kondrat, RM, Dremlyukh, NS, Ugrynovsky, AV \& Ksenych, AI 2015, 'Investigation of the foaming process using aqueous solutions of foaming surfactants and foam stabilizers', Scientific Bulletin of NMU, no. 3, pp. 20-26. [in Ukrainian]

[7] Kondrat, RM, Dremlyukh, NS, Ugrynovsky, AV \& Ksenych, AI 2017, 'Experimental studies of the solids flow back process from gas well bottomhole by applying foam systems, Exploration and development of oil and gas fields, no. 2 (63), pp. 90-96, 2017. [in Ukrainian]

[8] Kondrat, RM \& Dremlyukh, NS 2015, 'Study of the technological efficiency of washing a well from a sand plug in depleted fields using coiled tubing units and various flushing agents', Exploration and development of oil and gas fields, no. 1 (54), pp.72-80. [in Ukrainian]

[9] Pat. No. 58826 Ukraine, IPC E 21 B37/00, 'Device for destruction and removal of sand plugs', O.R. Kondrat, N.S. Diachuk, no. 201011886, application 07.10.2010, publ. 26/04/2011, bul. 8 .

[10] Pat. No. 98732 Ukraine, IPC E 21 B29/10, 'Device for casing repair', R.M. Kondrat, N.S. Diachuk, Ya.D. Klymyshyn no. 201103507, application 24.03.2011, publ. 11/06/2012, bul. 11 .

УДК 622.279

\title{
Інтенсифікація видобутку газу з родовищ з нестабільними резервуарами
}

\author{
Р.М. Кондрат, О.Р. Кондрат, Н.С. Дремлюх, А.В. Угриновський \\ Івано-Франківський національний технічний університет нафти $і$ газу; \\ вул. Карпатська, 15, Івано-Франківськ, 76019, Украӥна
}

Показано негативні наслідки винесення піску із пласта і методи запобігання утворенню піщаних пробок на вибої свердловин. За результатами експериментальних досліджень на моделі свердловини визначено мінімально необхідні швидкості руху газу для винесення частинок піску трьох різних фракцій. Визначено оптимальні концентрації пінотворних поверхнево-активних речовин (ПАР) і стабілізаторів у водних розчинах з метою отримання стійких пін для промивання піщаних пробок на вибоях свердловин. Експериментально визначено швидкості руху піни з додаванням і без додавання стабілізатора піни для винесення частинок твердої фази з свердловини. Розроблено дві композиції ПАР і стабілізатора піни, одна 3 яких пропонується для промивання піщаних пробок на вибої свердловини, а інша - для дозованого уведення у затрубний простір свердловини з метою запобігання накопиченню твердої фази на вибої.

Обгрунтовано вибір діаметра стовбура свердловини в зоні газоносного пласта залежно від продуктивності свердловини і визначено оптимальні значення товщини і проникності гравійної набивки у привибійній зоні з нестійкими колекторами, за яких запобігається винесення піску із пласта у свердловину. Наведено раціональні співвідношення діаметрів насосно-компресорних труб, колони гнучких труб і витрати агента для промивання піщаних пробок у свердловинах. Підібрано склад тампонажного розчину для створення у привибійній зоні пласта тампонажного каменю з високими значеннями міцності і проникності. Для підвищення ефективності та зменшення часу і витрат запропоновано пристрій для руйнування піщаних пробок. Запропоновано конструкцію пристрою для ремонту нижньої частини експлуатаційної колони, пошкодженої у результаті ерозійного руйнування частинками пластового піску.

Ключові слова: газ, ліфтові труби, піна, піщана пробка, тампонажний розчин, цементний камінь. 